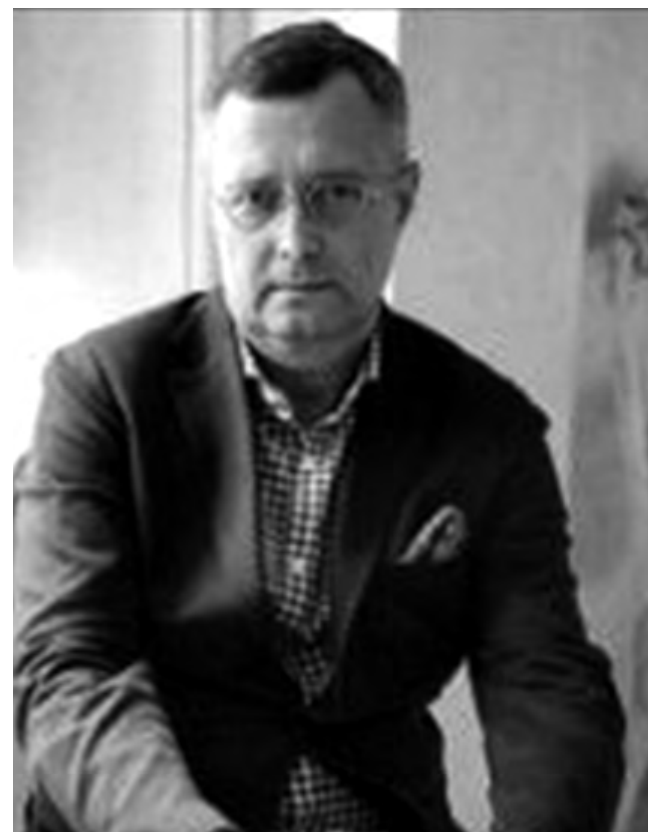

UDC:336.14

Bogdanenko Anatoliy Ivanovych, Ph.D. in public administration, Doctor of Science in Economics, Associate Professor of Public Administration, Interregional Academy of Personnel Management, 03039, Kyiv, Str. Frometivska, 2, tel.: (044) 26452 54, e-mail: Anatoliy Bogdanenko@ukr.net

ORCID: 0000-0003-0758-580

Богданенко Анатолій Іванович, доктор філософіі в галузі державного управління, доктор економічних наук, доцент кафедри публічного адміністрування, Міжрегіональна Академія управління персоналом, 03039, м. Київ, вул. Фрометівська, 2, тел.: (044) 26452 54, e-mail: Anatoliy_Bogdanenko@ukr.net

ORCID: 0000-0003-0758-5809

Богданенко Анатолий Иванович, доктор философии в отрасли государственного управления, доктор экономических наук, дочент кафедры публичного администрирования, Межрегиональная Академия управления персоналом, 03039, 2. Киев, ул. Фрометовская, 2, тел.: (044) 26452 54, e-mail: Anatoliy_Bogdanenko@ukr.net

ORCID: 0000-0003-0758-5809

DOI https://doi.org/10.32689/2617-2224-2019-16-1-24-34

\title{
INTERNATIONAL EXPERIENCE OF THE PUBLIC INVESTMENT POLICY AND POSSIBILITY OF ITS USE IN UKRAINE
}

Annotation. The article examines the experience of the state investment policy in different countries of the world. The distinctive features of the state investment policy of foreign countries are presented. The ways of using the experience of the state investment policy of the countries of the world to improve the state investment policy in Ukraine are offered.

The urgency of considering the generalization of international experience in the direction of the formation of the state investment policy and the possibility of its use in Ukraine through the implementation of the reform of economic processes in accordance with European standards is noted. Based on the experience of countries such as the USA, China, Austria, the Netherlands, Great Britain, France, Germany, Japan and Georgia, the distinctive features and features of the investment policy models of these countries on the way to the emergence of an 
innovative economy are detected, and differences in the forms of regulation of the investment mechanism are identified.

The need to include in the state investment policy of Ukraine the basic aspects of the main goals and objectives of the investment policy of the new generation, which takes into account the latest trends and needs of the world economy, is noted. This aspect is necessary on the path of Ukraine to European integration and requires the application of globally relevant approaches and priorities to the development of state investment policy.

It is concluded that a similar sign in the regulation of investment activities in Ukraine and in foreign countries is the implementation of a large influence of integration processes on the state investment policy. The state investment policy of Ukraine should become the basic direction of the state economic policy and ensure the formation of effective mechanisms for attracting investment resources to the development of the national economy. All measures cited in the article should provide an opportunity to ensure transparency and efficiency of public investments, direct investment flows to priority sectors of the economy, and create a basis for enhancing investment activity in Ukraine.

Keywords: state investment policy, investment companies, state investment activity, foreign capital, direct investments.

\section{СВІТОВИЙ ДОСВІД ДЕРЖАВНОЇ ІНВЕСТИЦІЙНОЇ ПОЛІТИКИ ТА МОЖЛИВОСТІ ЙОГО ВИКОРИСТАННЯ В УКРАЇНІ}

Анотація. Розглянуто досвід державної інвестиційної політики в різних країнах світу. Наведено відмінні особливості державної інвестиційної політики зарубіжних країн. Запропоновано шляхи використання досвіду державної інвестиційної політики країн світу для удосконалення державної інвестиційної політики в Україні.

Зазначено актуальність розгляду узагальненого світового досвіду у напрямі формування державної інвестиційної політики та можливості його використання в Україні через реформування економічних процесів відповідно до європейських стандартів. На основі досвіду таких країн, як США, Китай, Австрія, Нідерланди, Великобританія, Франція, Німеччина, Японія та Грузія, виявлені відмінні риси та особливості моделей інвестиційної політики цих країн на шляху до становлення інноваційної економіки, визначено відмінності у формах регулювання інвестиційного механізму.

Доведено необхідність включення в державну інвестиційну політику України базових аспектів основних цілей та завдань інвестиційної політики нового покоління, що враховує останні тенденції та потреби світової економіки. Цей аспект є необхідним на шляху України до євроінтеграції, і вимагає застосування актуальних у світовому масштабі підходів і пріоритетів до розвитку державної інвестиційної політики.

Визначено, що схожою ознакою регулювання інвестиційної діяльності в Україні і в зарубіжних країнах є великий вплив інтеграційних процесів на державну інвестиційну політику. Державна інвестиційна політика України 
має стати базовим напрямом економічної політики держави та забезпечити формування ефективних механізмів залучення інвестиційних ресурсів у розвиток національної економіки. Наведені заходи сприятимуть забезпеченню прозорості та ефективності державних інвестицій, спрямуванню інвестиційних потоків до пріоритетних галузей економіки, створенню підгрунтя для активізації інвестиційної активності в Україні.

Ключові слова: державна інвестиційна політика, інвестиційні компанії, державна інвестиційна діяльність, іноземний капітал, прямі інвестиції.

\section{МИРОВОЙ ОПЫТ ГОСУДАРСТВЕННОЙ ИНВЕСТИЦИОННОЙ ПОЛИТИКИ И ВОЗМОЖНОСТИ ЕГО ИСПОЛЬЗОВАНИЯ В УКРАИНЕ}

Аннотация. Рассматрен опыт государственной инвестиционной политики в разных странах мира. Приведены отличительные особенности государственной инвестиционной политики зарубежных стран. Предложены пути использования опыта государственной инвестиционной политики стран мира для совершенствования государственной инвестиционной политики в Украине.

Отмечена актуальность рассмотрения обобщеного мирового опыта в направлении формирования государственной инвестиционной политики и возможности его использования в Украине путем реформирования экономических процессов в соответствии с европейскими стандартами. На основе опыта таких стран, как США, Китай, Австрия, Нидерланды, Великобритания, Франция, Германия, Япония и Грузия, обнаружены отличительные черты и особенности моделей инвестиционной политики этих стран на пути к становлению инновационной экономики, определены отличия в формах регуляции инвестиционного механизма.

Доказана необходимость включения в государственную инвестиционную политику Украины базовых аспектов основных целей и заданий инвестиционной политики нового поколения, которое учитывает последние тенденции и потребности мировой экономики. Этот аспект является необходимым на пути Украины к евроинтеграции, и требует применения актуальных в мировом масштабе подходов и приоритетов к развитию государственной инвестиционной политики.

Отмечено, что похожим признаком регулирования инвестиционной деятельности в Украине и в зарубежных странах является большое влияние интеграционных процессов на государственную инвестиционную политику. Государственная инвестиционная политика Украины должна стать базовым направлением экономической политики государства и обеспечить формирование эффективных механизмов привлечения инвестиционных ресурсов в развитие национальной экономики. Приведенные меры будут способствовать обеспечению прозрачности и эффективности государственных инвестиций, направлению инвестиционных потоков в приоритетные отрасли экономики, созданию основы для активизации инвестиционной активности в Украине. 
Ключевые слова: государственная инвестиционная политика, инвестиционные компании, государственная инвестиционная деятельность, иностранный капитал, прямые инвестиции.

Proble statement. The problem of state investment policy remains one of the most urgent for many countries in the world. Different countries use different means and mechanisms to stimulate the development of their investment attractiveness at macro-, meso- and micro-levels in order to maximize the investment potential realization.

Ukraine is currently on the path to European integration, which requires the application of world-wide approaches and priorities for the development of state investment policy. Thus, the state investment policy of Ukraine should include the basic aspects of the main goals and tasks of the new-generation investment policy, taking into account the latest trends and needs of the world economy.

Since Ukraine is undergoing the reform of economic processes in line with the European standards, it is relevant to consider the generalization of the world's experience in the direction of the formation of a state investment policy and possibility of its use in Ukraine.

Analysis of recent publications on research issues. The papers of scientists, such as D. V. Vankovych, V. M. Geets, L. V. Gotsuliak, N. B. Demchyshchak, O. A. Kolodiziev, G. Koppern, M. I. Krupka, G. V. Markov, Yu. D. Prytyka, Ya. A. Soltys, F. P. Tkachyk and others are devoted to the consideration of state investment policy prob- lems. However, the analysis of publications on effective state investment policy is incomplete. At this stage of development of our country, it is necessary to study the world experience and possibility of its use in Ukraine to improve the state investment policy.

Purrose of the article. The purpose of the paper is to study the experience of the state investment policy of the world countries and the possibility of its application in Ukraine.

The investments are the resources for accelerating the processes of capital turnover of the business entities. They ensure the growth of profitability, form the priority directions of economic development, stimulate the restructuring of economic activity management system, provide the creation of high-tech industries, and increase the level of social standards. Through the investment resources, the GDP grows, and its redistribution between the parties to economic processes, branches of the economy is accelerated. At the same time, the development level of individual economic system components depends on state priorities and goals, which, in turn, should meet the basic needs of the society.

Most scientists take the view that the state investment policy shall mean the system of measures taken by the state towards the formation of necessary conditions for expansion of the investment activity, stabilization of 
the economic system and raising the performance efficiency of the business entities [1].

The result of state investment policy improvement should stimulate the development of intensification of the economy production component, increase in the level of entrepreneurial activity. Currently, the formation of national investment policies is targeted at new development strategies. In the interest of strengthening the productive capacity and sustainable development, the most states seek to attract foreign investments.

Let's consider the experience of the countries of the world, the economic development strategies of which could serve as an example for improving the formation of state investment policy in Ukraine.

So, the state investment policy for both American and foreign companies in the United States is aimed at attracting the investments. Currently, this country is in the first place in terms of scope of attracted foreign capital into the economy of its country. With regard to investments into the country, the USA adheres to the policy of maximum stimulation of foreign investors, while reserving the right to control the investments in the most sensitive sectors of the economy. The regulation of foreign investments in this country is carried out at the federal and the state levels. At the federal level, the general requirements are set for the foreign investments, and at the state level, the local government authorities of corresponding states set the specific requirements for the participation of foreign investors in projects. On the basis of long-term and short-term programs developed on the basis of local features and needs and in accordance with local legislation, each state independently works to attract the foreign investments [2, p. 116-117].

The state investment policy of China as part of a strategy of reforms and modernization largely defines the high rates of economic growth and social changes in China. It is increasingly extends towards the foreign and foreign economic course of the country, has an increasing influence on the economy of neighboring countries. It should be noted that China takes into account the scope of foreign investments in accordance with the concluded contracts, as well as the amounts of investments spent under such contracts. Obviously, the scope of spent investments is less than the scope under the contracts. The regulatory documents adopted in 2013 by the Chinese authorities, appeared to be a logical continuation of the state policy towards improving the investment climate, which commenced in 2012 [3].

Despite the quite attractive investment climate in China, the competition from advanced economies demands making active decisions by the authorities of such country, which would take into account new trends in the world investment market. In our opinion, this requires as follows:

- to simplify the procedures for approving the investment projects;

- to increase the efficiency of public authorities' activities by eliminating the duplication of functions and procedures;

- to reform the securities market and reform the judicial system.

Analysis of the state investment policy in Austria demonstrated that 
the country has no unified state act regulating the investment relations. The procedure and terms of investments and various forms of their stimulation are enshrined in a number of federal and land acts and directives on specific issues. The basic principle of the Austrian state investment policy is to provide the investors with the freedom to choose investment areas and sources of their funding. The state does not establish any direct restrictions on investment activity in any industry. At the same time, in some cases, the investments may be restrained by the need for obtaining a special permit for certain types of business activity, environmental protection requirements and other regulations not directly related to investment issues.

The foreign investors are provided with the national regime on a reciprocal basis in Austria. The foreign investments are allowed in all branches of its economy, except for defense industry, enterprises and organizations financed by the public funding (federal railways, postal and telegraph service, radio and television), as well as industries and activities which are state monopoly (mining, production of tobacco and alcoholic beverages).

The state investment policy of the Netherlands traditionally has the image of a country with a favorable investment climate due to the ease of registration of legal entities, absence of administrative barriers, favorable legal environment, primarily tax preferences, as well as a large number of international treaties on avoidance of double taxation. The attractiveness of the Dutch market for long-term investment projects has been increasing in recent years. The Government of the Netherlands consistently implements the strategy of attracting the foreign investments into the Netherlands based on the partnership of the state, business and science. The investment policy of the Netherlands is based on a intelligent presentation of investment projects to potential foreign partners. In the Netherlands there is a specialized state agency for foreign investments, which is a subdivision of the Ministry of Economy. In 2013, the Dutch government implemented a set of measures aimed at protection of the investments and financial support for small and medium-sized enterprises.

In our opinion, an example of an effective state investment policy which can be used for Ukraine is the experience of the EU countries Great Britain, France and Germany. The main mechanisms for state investment policy implementation in these countries are shown in Fig. 1.

The similarity of these mechanisms in the implementation of the state investment policy of these states is explained by the fact that they are typical for more developed countries, where the market economy has already strengthened and continues to evolve. Nevertheless, there are a number of differences in the forms of investment mechanism regulation.

Thus, the following differences may be identified in the quality of typical features of state investment policy of Great Britain (Fig. 2).

A special place in the investment activity regulation in Germany is also given to investment companies the operation of which is regulated by the Law on investment companies. De- 
The main mechanisms of state investment policy implementation

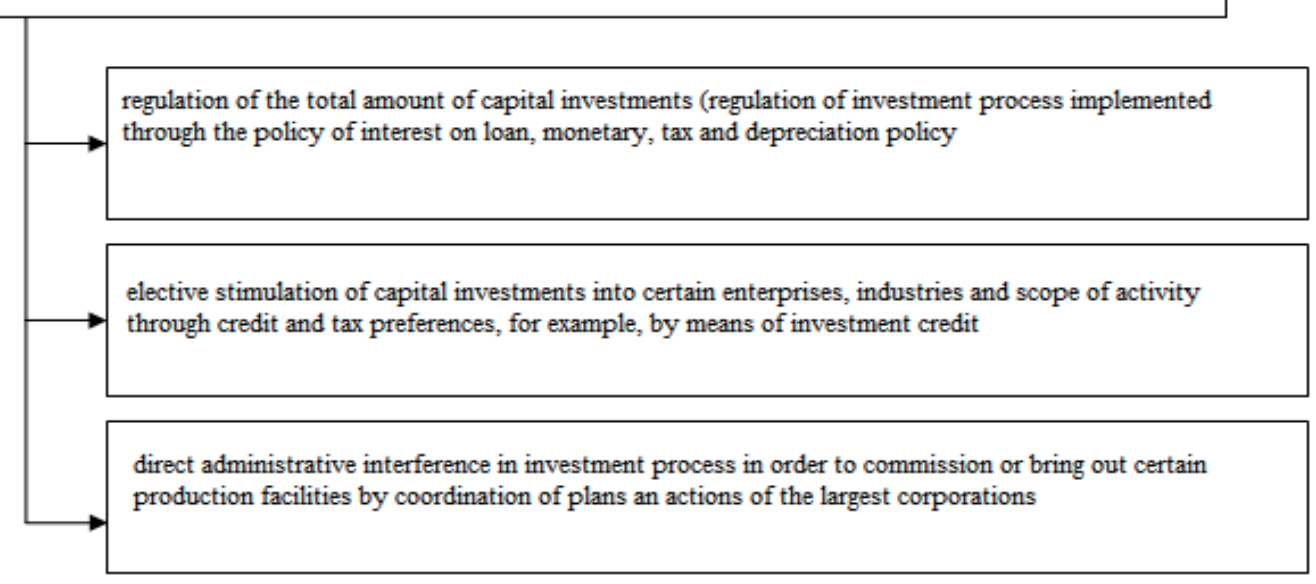

\section{Fig. 1. The main mechanisms for implementing the state investment policy of Great Britain, France and Germany}

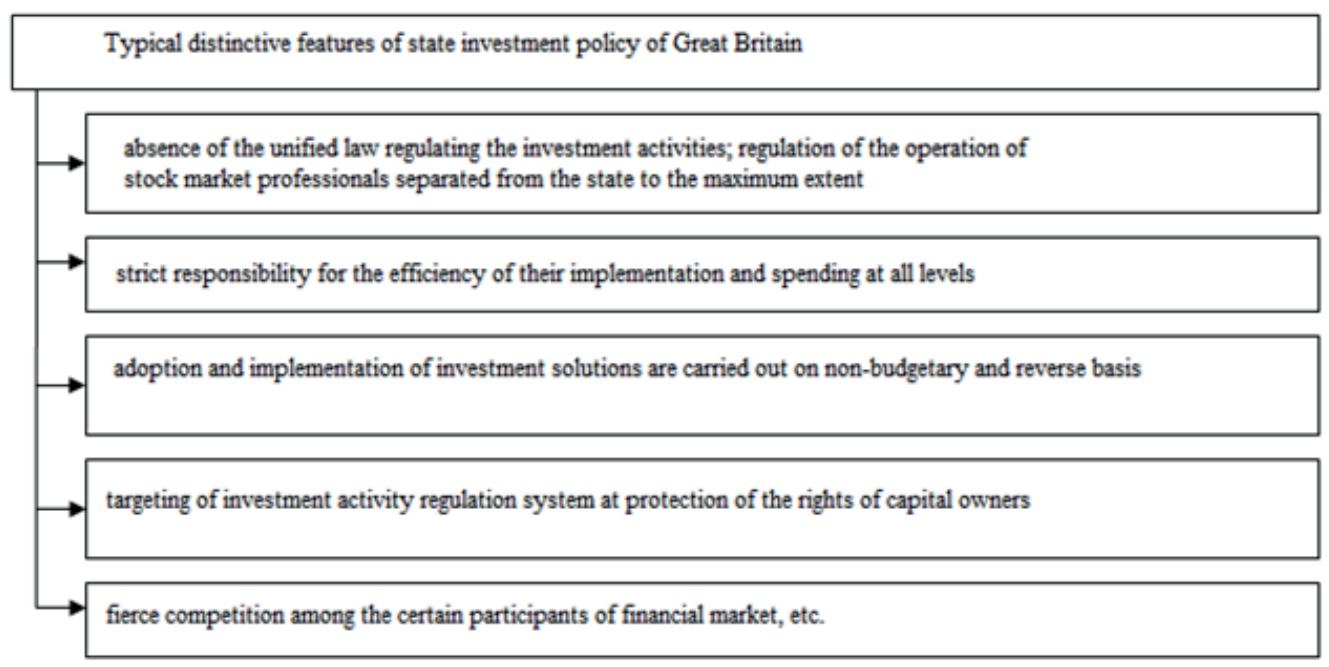

Fig. 2. Typical distinctive features of state investment policy of Great Britain

scribing the regulation of the investment process in Germany, I would like to note its orientation towards the domestic financial institutions. And the following may be identified as general distinctive features of the German system of investment sphere legal regulation (Fig. 3).
In France there is no unified special law regulating the foreign investments. Nevertheless, there is a system of "prior notification of the authorities about the intention to extend the testing period" which applies mainly to investors from non-EU countries if they participate in the activities of the French company. 


Typical distinctive features of state investment policy of Germany
absence of unified law and body regulating the investment activities in Germany
and depress the investors' opoortunity to choose
$\begin{aligned} & \text { high degree of control providing the govrnment with maximum convenience of control function } \\ & \text { implementation }\end{aligned}$
rigorous progressive taxation of income of business entities
strict system of surplus profit taxation and tax sanction for unfair
price competitiveness
low level of risk to lose the funds invested into the investment fund

Fig. 3. Typical distinctive features of state investment policy of Germany

\begin{tabular}{|c|c|} 
Typical distinctive features of state investment policy of France \\
absence of unified law regulating the investment activities in the country \\
system of "prior notification of authorities" \\
clear distinction between the direct and other foreign investments, etc.
\end{tabular}

Fig. 4. Typical distinctive features of state investment policy of France

In the French legislation, there is also a clear distinction between the direct and other foreign investments, which is explained by the application of more preferential regulation in the course of latters' relations. Thus, the following may be identifies as the main distinguishing features of the French model of investment process regulation (Fig. 4).
Summarizing the experience of the leading EU countries of Germany and France, we should note that governments apply the selective approach to each individual investment direction using a fairly wide range of fiscal instruments (tax preferences, subsidies, etc.).

It should be noted that developed countries see the basis of their compe- 
titiveness in the long-term perspective, namely in the innovative development of own economy in the area of energy and ecology, transport, information and telecommunication systems, and health care.

The governments of the United States, the EU and Japan are convinced that innovation technologies in these areas will enable them to form new, post-crisis technological patterns able to provide the basis for dynamic economic growth, global economic leadership, and address the social problems (health care, unemployment). In other words, the state policy of these countries is aimed at fiscal stimulation of mentioned directions.

Currently, the increase of the efficiency of state investment programs' implementation is quite topical in Ukraine. The questions still remain about choosing the methods of financing, holding of expert review, control and monitoring of state investment programs. The experience of Georgia is quite interesting for Ukraine. There are three Free Industrial Zones in the country, which create the conditions for effective support of international trade and tax exemption for international companies. The Law on Free Industrial Zones was adopted in order to support the investments in Georgia, stimulate exports and develop international trade and transit activities. Favorable taxation and customs control conditions in the Free Industrial Zones provide the powerful incentives for foreign companies to move their production facilities into these zones. The availability of Free Industrial Zones has contributed to the growth of industry by providing new opportunities for investments in industries such as metallurgy, petrochemical industry, motor industry, pharmaceuticals, electronics, production of medical equipment and building materials. Companies which place their production facilities in Free Industrial Zones may receive the following incentives:

- enterprises located in the Free Industrial Zones are exempted from property tax;

- VAT is not imposed on goods purchased abroad and imported into these zones;

- VAT is not imposed on transactions between enterprises located in Free Industrial Zones;

- provision of goods / services between enterprises in these areas is not subject to VAT;

- foreign goods imported into Free Industrial Zones are not subject to import duties;

- products manufactured in these zones are subject only to VAT within the special customs regime, regardless of the quantity of goods;

- export of goods manufactured in the FIZs to the territory of Georgia is not subject to import duties;

- exchange transactions are not controlled, no barriers to trade or quotas;

- no restrictions on the repatriation of capital;

- profit received by a foreign company as a result of operation in Free Industrial Zones is not subject to income tax;

- employees of enterprises located in the Free Industrial Zones personally pay the income tax by declaration of income, since the enterprise located in these zones is not an agent which pays 
the taxes for employees and thus is not required to withhold the tax from wages [4].

Also note that agricultural enterprises do not pay VAT, are not subject to income tax and do not pay import duties on agricultural equipment. It should be noted that the agriculture received additional benefits from free trade regimes, which are free trade agreements, where the European Union provides the developing countries with preferences in access to its market.

Summarizing the experience of Georgia, we would like to note that in Ukraine there was an attempt to stimulate the investments by creating the special economic zones, but unfortunately, we did not succeed in obtaining a certain result. But the application of agricultural support experience is quite realistic for implementation in Ukraine.

Thus, in the analyzed foreign countries, as well as in Ukraine, the integration processes taking place in the world in recent years have a great influence on the state investment policy. This is a similar feature in the regulation of investment activity in Ukraine and foreign countries. However, there are some differences which Ukraine should take into account in the formation of an effective investment model of the state. For example:

- from the USA - Ukraine could borrow a rigid control system for investment activity;

- from Japan - scrupulousness about the potential investors;

- from France - policy aimed at reducing the risk of finances deposited into the investment funds;
- from the Great Britain - an effective incentive policy;

- from Germany - a system of "prior notification of power bodies", etc.

All this would enable the Ukrainian state to successfully integrate into the system of world economy and take its place among the export-import turnover in the world. And the unified political and economic course in the area of foreign investment development applied in all the above-mentioned developed foreign countries, should serve as an example for Ukraine in order to form an effective system of investment legislation.

Conclusion and prospects for further research. Thus, summarizing the above, one can conclude that the state investment policy of Ukraine should become the basic direction of the state's economic policy and ensure the formation of effective mechanisms for attracting the investment resources into the development of the national economy.

Based on the analysis of global experience of public investments, we recommended the following approaches in the state investment policy of Ukraine:

- to bring the regulatory framework in compliance with the European standards;

- to expand the sphere of budget investments by triggering the activities of the State Bank for Reconstruction and Development in order to support the priority development directions;

- to review the implementation of the current state programs with respect to expediency, quantity, impact on the industry and the economy as a whole;

- using the advanced experience of developed countries, to introduce new 
forms of support for industries such as the coal industry, agriculture, which would stimulate the national private investments in this direction;

- to reorient the state investments towards economic and social infrastructure and innovation programs which would ensure the transition of the country's economy to high-tech and knowledge-intensive industries, enabling to increase the competitiveness of Ukrainian enterprises in the world market.

All of the above-mentioned measures will make it possible to ensure the transparency and efficiency of state investments, to direct the investment flows towards priority sectors of the economy, and to create the basis for intensifying the investment activity in Ukraine.

\section{REFERENCES}

1. M. I. Krupka, D. V. Vankovych, N. B. Demchyshak, M. I. Kulchytskyi (2011), "Formation of financial potential of investment activity in the economy of Ukraine: monograph", Lviv: LNU imeni Ivana Franka, p. 404.

2. Holenishcheva Ye. Yu. (2016), "Features of the formation and implementation of state investment policy in different countries of the world", Visnyk Natsionalnoho universytetu tsyvilnoho zakhystu Ukrainy. Derzhavne upravlinnia, vol. 1, p. 115122.

3. Novoselova L. V. (2016), "About the implementation of the investment component of the strategy of eco- nomic growth in the PRC”, Rossiyskiy ekonomicheskiy zhurnal, vol. 4, p. $63-72$.

4. Zatonatska T. H. (2014), "World experience in the formation of investment policy and mechanisms for its implementation”, Visnyk Kyivskoho natsionalnoho universytetu imeni Tarasa Shevchenka. Ekonomika, vol. 8, p. $6-10$.

\section{СПИСОК ВИКОРИСТАНИХ ДЖЕРЕЛ}

1. М. I. Крупка Формування фінансового потенціалу інвестиційної діяльності в економіці України: монографія / М. І. Крупка, Д. В. Ванькович, Н. Б. Демчишак, М. І. Кульчицький - Львів: ЛНУ імені Івана Франка, 2011. - 404 с.

2. Голеніщева $Є$. Ю. Особливості формування та реалізації державної інвестиційної політики в різних країнах світу / С. Ю. Голеніщева // Вісник Національного університету цивільного захисту України. Серія: Державне управління. - 2016. Вип. 1. - С. 115-122.

3. Новоселова Л. В. О реализащии инвестиционной составляющей стратегии экономического роста в КНР/ Л. О. Новоселова // Российский экономический журнал. - 2016. №4. - C. 63-72.

4. Затонацька T. Г. Світовий досвід формування інвестиційної політики та механізмів іiі реалізації / T. Г. Затонацька // Вісник Київського національного університету імені Тараса Шевченка. Економіка. - 2014. - Вип. 8. - С. 6-10. 